\title{
TWO-STAGE ANAEROBIC DIGESTION OF ORGANIC WASTES: A REVIEW
}

\author{
I. Simeonov, L. Kabaivanova, E. Chorukova
}

\begin{abstract}
Anaerobic digestion is a biotechnological process, in which microorganisms degrade the complex organic matter to simpler components under anaerobic conditions to produce biogas and fertilizer. This process has many environmental benefits, such as green energy production, organic waste treatment, environmental protection and greenhouse gas emissions reduction.

It has long been known that the two main communities of microorganisms (acidogenic and methanogenic) taking part in the anaerobic digestion differ in many aspects e.g. their optimal conditions for cell growth and development. Therefore, the anaerobic digestion in a single bioreactor (BR) (single-phase process) required selected optimal conditions, taking into account the slow-growing methanogens at the expense of fast-growing acidogens, which affects the efficiency of the whole process. This has led in recent years to development of two-stage anaerobic digestion, in which the processes are divided into a cascade of two separate BRs. It is known that this separation of the processes into two consecutive BRs leads to significantly higher energy yields for the two-phase system $\left(\mathrm{H}_{2}+\mathrm{CH}_{4}\right)$, compared to the traditional single-stage $\mathrm{CH}_{4}$ production process.

The present paper aims to review the literature in the field of two-stage anaerobic digestion of organic wastes.
\end{abstract}

Keywords: two-stage anaerobic digestion, hydrogen, methane, mathematical models

\section{INTRODUCTION}

Anaerobic digestion (AD) of organic wastes is a very attractive biotechnology during last years mainly in the field of the renewable energy sources and biofuels. This biotechnology is very useful for depolluttion of highly polluted with organics wasted waters and municipal wastes. However, using a variety of wastes and residuals as substrate and mixed cultures in the bioreactor makes $\mathrm{AD}$ as one of the most complicated biochemical processes employing hydrolytic, acidogenic, hydrogenproducing, acetate-forming bacteria as well as acetoclastic and hydrogenoclastic methanogens. Hydrogen $\left(\mathrm{H}_{2}\right)$ and volatile fatty acids (VFAs) including acetic, propionic, isobutyric, butyric, isovaleric, valeric and caproic acid and other carboxylic acids such as succinic and lactic acids are formed as intermediate products. As these acids are important precursors for various industries as mixed or purified chemicals with high market value, the $\mathrm{AD}$ process can be bioengineered to produce VFAs alongside $\mathrm{H}_{2}$ and therefore biogas plants can become biorefineries [Wainaina et al., 2019]

Certain organic wastes, however, cannot be easily digested due to their low nutrient level insufficient for $\mathrm{AD}$, thus anaerobic co-digestion (AcoD) (digestion of mixures of organic wastes) is a viable option. Numerous studies have shown that using co-substrates in AD systems improve methane yields as positive synergisms are established in the digestion medium, and the supply of missing nutrients are introduced by co-substrates. Synergistic effects among different chemical components under the AcoD process played an important role in improving its performance [Hubenov et al., 2015; Chow et al., 2020; Zhang et al., 2021].

$\mathrm{AD}$ is a multi-step biotechnological process with $\mathrm{H}_{2}$ as a non-accumulating intermediate product [Ruggeri, et al, 2015; Achinasb and Jan Willem, 2017]. Recently, the interest in $\mathrm{H}_{2}$ production through AD, has increased [Ausiello. et al., 2017; Tashyrev, et al., 2018; Bakonyi et al., 2019; Hovorukha et al., 2021]. This is due to the fact that the rates of $\mathrm{H}_{2}$ production are rather high and a variety of feedstock can be used as a substrate. In traditional $\mathrm{AD}, \mathrm{H}_{2}$ is consumed immediately e.g. by hydrogenotrophic methanogens to produce $\mathrm{CH}_{4}$ and $\mathrm{CO}_{2}$ [Gerardi, 2003]. On the other hand, $\mathrm{H}_{2}$ can be produced separately by engineering the process conditions. However, the main limitation of dark fermentative $\mathrm{H}_{2}$ production is the rather low energy recovery. In order to completely utilize the organic acids produced during dark fermentation and improve the overall energy conversion efficiency, a two-stage $\mathrm{AD}$ concept (TSAD) consisting of hydrogenic process followed by methanogenic process has been suggested [Demirer and Chen, 2005; Chu et al, 2012; Ruggeri, et al, 2015]. In the TSAD system (Fig. 1), relatively fast growing acidogens and $\mathrm{H}_{2}$ producing microorganisms are grown in the first-stage, the hydrogenic bioreactor $\left(\mathrm{BR}_{1}\right.$ with working volume $\left.\mathrm{V}_{1}\right)$. They are involved in the production of VFAs and $\mathrm{H}_{2}$. On the other hand, the slow growing acetogens and methanogens are grown in the second stage, the methanogenic bioreactor $\left(\mathrm{BR}_{2}\right.$ with working volume $\left.\mathrm{V}_{2}\right)$ in which the produced VFAs are further converted to $\mathrm{CH}_{4}$ and $\mathrm{CO}_{2}$. It is known that the overall energy recovery 
resulted in significantly higherdegree for the twostage $\mathrm{H}_{2}+\mathrm{CH}_{4}$ system, as compared to the traditional one-stage $\mathrm{CH}_{4}$ production process [Ruggeri, et al, 2015].

In our laboratory experimental studies of codigestion of mixtures of milk, whey and wasted activated sludge from the Sofia waste waters treatment plant in two-stage process we obtained degree of biodegradation (DBD) of $95 \%$ [Simeonov, 2005]. In the case of two-stage processes with production of methane only, the obtained digestate may be used as a natural fertilizer in agriculture.

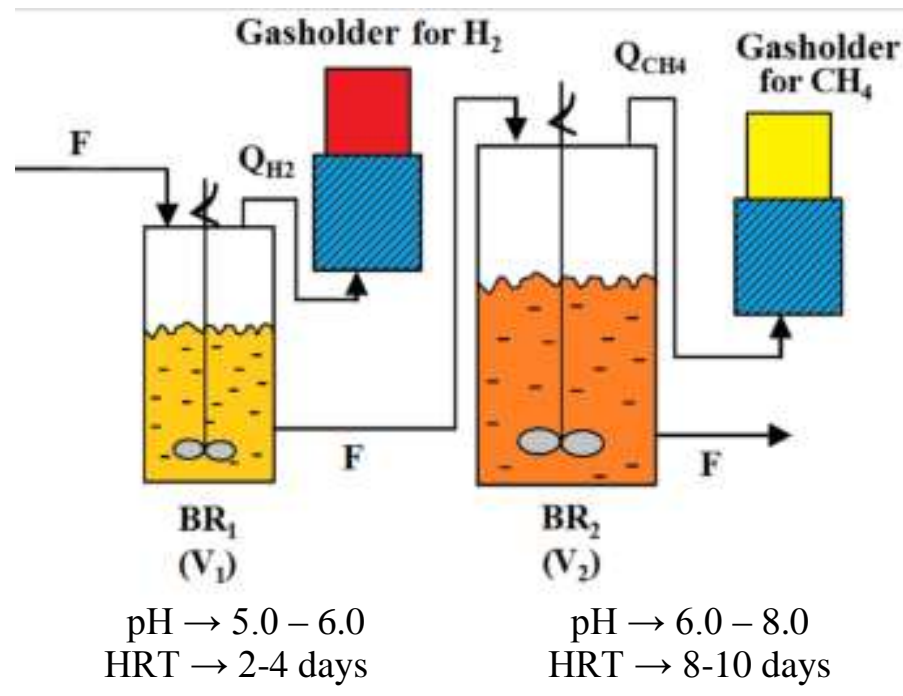

Fig. 1. Scheme of two-phase process of $\mathrm{AD}$ with simultaneous production of $\mathrm{H}_{2}$ and $\mathrm{CH}_{4}$.

Assume that the volumes $V_{1}$ and $V_{2}$ of the bioreactors are constant. Let $\mathrm{F}_{1}$ and $\mathrm{F}_{2}$ be the inflows in the $\mathrm{BR}_{1}$ and $\mathrm{BR}_{2}$ respectively and let $\mathrm{F}_{1}=\mathrm{F}_{2}=\mathrm{F}$ be valid. It is well known that the dilution rates $D_{1}$ and $\mathrm{D}_{2}$ are defined as (1):

$$
\mathrm{D}_{1}=\mathrm{F} / \mathrm{V}_{1}, \mathrm{D}_{2}=\mathrm{F} / \mathrm{V}_{2},
$$

then $\mathrm{D}_{2}=\left(\mathrm{V}_{1} / \mathrm{V}_{2}\right) \mathrm{D}_{1}=\gamma \mathrm{D}_{1}$ within $\gamma=\mathrm{V}_{1} / \mathrm{V}_{2}$

It is known that the $\mathrm{V}_{2}$ of the $\mathrm{BR}_{2}$ for methane production is larger than the volume $\mathrm{V}_{1}$ of the $\mathrm{BR}_{1}$. Therefore, the constant $\gamma<1$ should be valid.

The TSAD process is based on the different function between acidogens and methanogens in physiology, nutrition needs, growth kinetics, and sensitivity to environmental conditions. In the first stage, the substrate is transformed to $\mathrm{H}_{2}, \mathrm{CO}_{2}$, VFAs, lactic acid and alcohols by acidogens with optimal $\mathrm{pH}$ of 5.0-6.0 and hydraulic retention time (HRT) of 1-3 days. In the second stage, the remaining VFAs, lactic acid, and alcohols in the BR producing $\mathrm{H}_{2}$ effluent are converted to $\mathrm{CH}_{4}$ and $\mathrm{CO}_{2}$ by methanogens under optimal $\mathrm{pH}$ range of 7.0-8.0 and HRT of 10-15 days.

The bottle-neck problems occur in the firste stage (production of $\mathrm{H}_{2}$ ) of the TSAD. In this process by a mixed anaerobic and facultative bacterial population, various metabolic pathways can be simultaneously present during $\mathrm{H}_{2}$ production.
The main aspects of TSAD have been confirmed with experimental tests, either in batch or in continuous modes, using two feeds representative of organic refuses [Rafieenia Ret al., 2018]. Experimental results show that the energy produced as $\mathrm{H}_{2}$ and $\mathrm{CH}_{4}$ gases is higher than the harvested energy using a one-step AD; specifically it is in the range of 1.5-2.7 times higher [Ruggeri, et al, 2015].

The combination of biohydrogen and biomethane production from organic wastes via TSAD could yield a biohythane gas with a composition of 10$15 \% \mathrm{H}_{2}, 50-55 \% \mathrm{CH}_{4}$ and $30-40 \% \mathrm{CO}_{2}$ with high potential to be used as vehicle fuel [Ruggeri et al., 2015; O-Thong et al., 2018].

In the early publications concerning TSAD processes production of methane only in both bioreactors is observed (old approach) [Simeonov, 2005; Parawira et al., 2007], while in the recent publications co-production of $\mathrm{H}_{2}$ (in the $\mathrm{BR}_{1}$ ) and $\mathrm{CH}_{4}$ (in the $\mathrm{BR}_{2}$ ) is available (new approach).

Some review papers in this field are known. In [Sompong O-Thong, et al., 2018] the first review of TSAD is presented. On the base of 132 references the general approach of biohythane production via two-stage $\mathrm{AD}$ (principles, microorganisms, reactor configuration, process parameters, methods for improving productivity as well as technical challenges toward the scale-up process of biohythane process) 
are outlined. In [Nabaterega et al., 2021-137 references] a review on TSAD options for optimizing municipal wastewater sludge treatment process is presented. A multi-criteria analysis performed on 51 data points obtained from the literature showed the thermophilic-mesophilic (T-M) two-stage AD as the best option for overall \% improvement in volatile solids removal and $\mathrm{CH}_{4}$ yield over the control among the six two-stage configurations. Additionally, T-M also achieves higher pathogen reduction and better dewaterability. This article provides a guide for the implementation and practical applicability of the two-stage AD process for wastewater treatment plants. In [D'Silva et al., 2021 - 174 references] a review on microbial biogas enrichment possibilities are presented on focus as a $\mathrm{CO}_{2}$ utilization technique, which converts $\mathrm{CO}_{2}$ into $\mathrm{CH}_{4}$ through specific $\mathrm{H}_{2}$ utilizing microbial species. It was outlined that the TSAD strategy could be the best strategy able to upgrade reliably the existing AD systems to $\mathrm{H}_{2}$ assisted pathways. In [Cremonez et al., $2021-205$ references] a review evaluating the scenario and viability of the multi-stage $\mathrm{AD}$ process applied to agroindustrial effluents is presented. It is outlined that the great challenges are focused on the stability of the composition and yield of $\mathrm{H}_{2}$ in the acid phase, besides the problems resulting from the treatment of complex residues. From a technical point of view, future research targeting the isolation and immobilization of stable and adapted bacteria to the digestion process, together with studies on the combination of specific biodigesters, pre-treatments, and substrate mixtures, are necessary. The development of this sector is fundamental to reach high levels of technological maturity, enabling the scale-up of two-stage digestion, which in most cases occurs only at the bench or pilot scale. In [Rabii et al., 2019 - 131 references] a review of anaerobic co-digestion including the effect of TSAD processes is presented. In [Wei and Liu, 2018 - 27 references] it is outlined that at present, TSAD technology is in its testing stage and according to some researches it is not suitable for some kinds of waste processing. In [Khan et al., 2016 - 100 references] a review that combines the optimization approaches for methane, VFAs and biohydrogen production from the $\mathrm{AD}$ is presented. In this review study, the types and configurations of the bioreactor are discussed for each type of product. It is outlined that by adapting the same anaerobic system for VFAs, biohydrogen and methane individually or simultaneously it could be significantly improved the economic and environmental sustainability. However these reviews discussed some particular cases.

The recent survey presents the state of the art (on the base of 163 references, from 2002 to 2022 and our own stidies), including the influence of different parameters, types of bioreactors, microbiology aspects, mathematical modelling and energetical considerations on TSAD processes

\section{FEEDSTOCKS (SUBSTRATES)}

A large quantity of organic waste produced by agriculture, industry and domestic processes are treated by TSAD processes:

1. Activated sludge (AD and AcoD) [Chow et al., 2020; Zhang et al., 2021; Athanasoulia et al., 2012; Simeonov, 2005; Watts et al., 2006; Zhu and. Béland, 2006; Shia at al., 2021; Sun et al., 2022; Forouzanmehr et al., 2021];

2. Municipal wastewaters [Nabaterega et al., 2021; Li and Yu 2016; ];

3. Organic fraction of municipal solid wastes [Bakonyi et al., 2019; Kumar and Samadder, 2020; Lavagnolo et al., 2018; Rocamora, et al., 2020; Ding et al., 2021; Nguyen et al., 2021];

4. Industrial wastes [Ramadhani et al., 2021; Krishnan et al., 2016; Fuentes et al., 2021; Kamyab and Zilouei; 2021];

5. Agroindustrial waste - milk whay, sugarcane vinasse, manipueira, vinasse, tequila vinasses, highly concentrated winery effluents, dairy manure, dairy wastewater, abattoir wastewater [Aruna Devi et al, 2018; Cremonez et al., 2021; Buback dos Santos et al., 2021; Ramos et al., 2021; Demirer and Chen, 2005; Guo et al., 2010; Rodriguez et al., 2013; Hailu et al., 2021; Vital-Jacome and Buitron, 2021];

6. Sugarbeet [Hussy, et al., 2005];

7. Cassava [Okudoh et al., 2014];

8. Grass and maize silage [Nizami and Murphy, 2011; Illi et al., 2021];

9. Organic solids waste [Kumar et al., 2020; Lin and Lay, 2003. Chu and Wang, 2017; Khalid, et al., 2011];

10. Palm oil mill effluent [Krishnan et al., 2016; O-Thong et al., 2008 ; Ramadhani et al.,2021; Sani et al., 2021];

11. Food waste and food wastewater [Ariunbaatar al., 2015; Chatterjee and Mazumder, 2018; Bolzonella et al., Yun, et al., 2018; Pramanik et al., 2019; Meena et al., 2020; Srisowmeya et al., 2020; Chu et al., 2012; Fenghao et al., 2011; Komiliset al., 2017; Pramaniket al., 2019; Seung et al., 2010; Srisowmeya, et al., 2020; Wang and You-cai, 2009; 
Xiaoa et al.,2018; Hou et al., 2021a; Hou et al., 2021b; Hassan et al., 2021; Rusín et al., 2021];

12. Organic market waste [Gómez et al., 2019];

13. Kitchen waste [Jayalakshmi, et al., 2009; Yan et al., 2021 - waste cooking oil];

14. Fruit and vegetable waste [Parawira et al., 2007; Ganesh et al., 2014; Chatterjee and Mazumder, 2018];

15. Pharmaceutically active compounds [Gallardo-Altamirano et al., 2021];

16. Residual fermented solids obtained after biodiesel production [dos Santos et al., 2021]. The reported process offers the possibility of integration among three biofuels of industrial interest (biodiesel, bio-hydrogen, and biomethane), according to the biorefinery principles, which target the maximum utilization of biomass to produce a variety of products.

17. Mixtures (co-digestion) of organic waste [Baldi et al., 2019; Esposito et al., 2012; Hubenov et al., 2015; Li and Fang, 2007; Martinez-Burgoset al., 2021; Silva Fabrícia et al., 2018; Notodarmojo et al., 2022; Tena et al., 2021; Tsigkou et al., 2021; Chen at al., 2021 - swine manure and rice straw; Hailu et al., 2021 - abattoir wastewater, heterogeneous fruitsvegetables solid waste, and their combination; Yan et al., 2021 - waste cooking oil and sewage sludge, Náthia-Neves et al., 2018 - restaurant food waste and vinasse, a waste from sugarcane industry].

All authors concluded that the chemical nature of the substrate greatly influences the process and the $\mathrm{pH}$ optimum for acidogenesis. Each type of biomass contains a great variety of organic and inorganic elements that considerably affect the digestion process. The increase in biogas production is directly dependent on the content of the substrates submitted to this process (Rasapoor et al., 2020).

Not only the quality but also the amount of solids in the substrates submitted to digestion affects considerably the whole process (Elbeshbishy et al., 2017). Digestion systems for biogas production may be classified according to the load of total solids in liquid digestion, where the content of Total Solids (TS) is less than $15 \%$ and solid digestion, with levels above 15\% (Liu et al., 2016). Komilis et al. (2017) also classify the process in wet (TS of the raw material $\leq 10 \%$ ), semi-dry (TS of the raw material $10-20 \%$ ), and dry (TS of the raw material $\geq 20 \%$ ) digestion.

In general, liquid digestion systems present higher intensity reactions with substrate, short retention times in the reactors, while digesters operating with solid digestion present lower reactor volumes (due to lower dilution of the diluted substrates), but also lower energy requirements (Kainthola et al., 2019).

Carbohydrates are the best substrate for this process. Many organic refuses consist not only of carbohydrates, but also of complex colloidal particles such as proteins and lipids; agricultural crops often have a high content of water and sugar being well suited as substrates for fermentation. In recent years an interesting substrate for TSAD process are lignocelluloses in organic waste [Yang, et al., 2015]

\section{REACTORS CONFIGURATION FOR BIOHYTHANE PRODUCTION}

Different BRs were used as $\mathrm{H}_{2}$ or $\mathrm{CH}_{4}$ production reactors in TSAD. More than $95 \%$ of the working industrial biogas plants operate with CSTRs. However, a lot of studies are dedicated to new type of bioreactors as follows:

1) Bioflm reactors [Mohan et al., 2008];

2) Membrane BRs [Chaikasem et al., 2014];

3) Upflow Anaerobic Sludge Blanket (UASB) reactors [Aruna Devi et al, 2018; Nizami and Murphy, 2011;]; fixed-bed up-flow BRs [Rodriguez et al., 2013];

4) Anaerobic fluidized bed reactor (AFBR) [Ramos et al., 2021; Ramadhani et al. 2021];

5) Solid-state anaerobic BRs [Ding et al., 2021 first-stage solid-state digester and a second-stage liquid digester];

6) Anaerobic sequence batch reactors (ASBR) [Hailu et al., 2021];

7) Combinations: 2016];

a) BR1 - UASB, BR2 - CSTR [Krishnan et al.,

b) BR1 - CSTR, BR2 - anaerobic sequencing batch reactor (ASBR) and UASB [Sani et al., 2021];

c) BR1 - CSTR, BR2 - UASB [Kamyab and Zilouei; 2021]; 2021];

d) BR1 - UASB, BR2 CSTR [Sposob et al.,

e) BR1 - solid-bed reactor, BR2 -UASB [Parawira et al., 2007].

\section{TEMPERATURE AND pH}

\subsection{Temperature}

Temperature is one of the most important factors affecting the growth of microorganisms. The operating temperature influences the growth rate of bacteria by influencing the biochemical reactions responsible for the maintenance of homeostasis and 
their metabolism. $\mathrm{H}_{2}$-producing dark fermentation reactors can be operated in various temperature ranges from mesophilic $\left(35-45^{\circ} \mathrm{C}\right)$, thermophilic $\left(55-60^{\circ} \mathrm{C}\right)$ to extreme thermophilic $\left(70-80^{\circ}\right)$ conditions. Most of the $\mathrm{H}_{2}$ dark fermentation studies have been conducted at temperature range of $35-45^{\circ} \mathrm{C}$.

Temperature is also a very important operation factor in the second stage for anaerobic digestion process. It determines the rate of anaerobic digestion process, particularly the rate of hydrolysis and methanogenesis. The thermophilic process could accelerate the biochemical reactions and give higher degradation efficiency as well as higher $\mathrm{CH}_{4}$ production rates compared to mesophilic condition [Watts and Keller, 2006]. As temperature increases, the rate of retention time process is much faster and this results in more efficient operation and lowers the retention time requirement [Van Niel et al., 2003]. Thermophilic condition also increases in thermodynamic favorability of $\mathrm{CH}_{4}$-producing reactions, decreases solubility of $\mathrm{CH}_{4}$ and $\mathrm{CO}_{2}$, and destruction of pathogens in the reactor effluent. Methanogens are extremely subtle to change in temperature and even a small temperature variation $\left(2-3^{\circ} \mathrm{C}\right)$ can lead to VFAs accumulation. This decreases the $\mathrm{CH}_{4}$ production rate for methanogens, especially at the thermophilic conditions. Maintaining the stable temperature is important for biohythane production.

The AD process may be classified according to temperature, as [Divya et al., 2015; Kumar et al., 2020]:

1. Psychrophilic (below $20^{\circ} \mathrm{C}$ );

2. Mesophilic $\left(20-45^{\circ} \mathrm{C}\right)$;

3. Thermophilic $\left(55-70{ }^{\circ} \mathrm{C}\right)$.

Mesophilic bands are interesting because they make up the average temperature of most tropical countries. In addition, they ensure greater process stability and greater diversity of active anaerobic microorganisms [Kainthola et al., 2019]. Processes conducted in this temperature range are widely used when high methane levels are required, either from the process as a whole or from the digestion phase. In contrast, temperatures encompassed by the thermophilic range ensure higher rates of organic loading and initial hydrolysis of the substrates, reducing hydraulic retention times and providing higher yields of biogas production (Kainthola et al., 2019). Besides the fact that high temperature limits the amount of active microorganisms, it should be noted that the rapid degradation and production of toxic compounds might affect or inhibit the development of methanogenic microorganisms
(Kainthola et al., 2019). Saratale et al., 2018) stated that the sharp increase in temperature results in an increase in the mortality rate of methanogenic organisms compared to the mesophilic phase temperatures. On the other hand, the same conditions also considerably reduced the concentration of pathogens harmful to the process (Panigrahi and Dubey, 2019), besides being interesting for systems aimed at obtaining hydrogen as a final product. Based on this, two-stage systems can be observed using thermophilic temperatures (55 $\left.{ }^{\circ} \mathrm{C}\right)$ during the hydrolysis and acidification phase of the material and later mesophilic conditions $\left(35^{\circ} \mathrm{C}\right)$, ensuring higher stability and diversity of methanogenic Archeas in the methane production phase (Wang et al., 2018; Chen and CHANG, 2020; LI et al., 2020b). A similar condition was also reported in a study conducted by Ruffino et al. (2020), using temperatures of $50{ }^{0} \mathrm{C}$ for the acid phase and $38{ }^{\circ} \mathrm{C}$ for the methanogenic phase. The authors obtained an increase in DBD from $42 \%$ to $55 \%$ and an increase in methane production from 280 to $332 \mathrm{~L} / \mathrm{kg}$ added organics.

Existing combination for TSAD:

1) Mesophilic-mesophilic [Gallardo-Altamirano et al., 2021; Nguyen et al., 2021; Shia at al., 2021; Náthia-Neves et al., 2018]

2) Termophilic- mesophilic [Krishnan et al., 2016; Ramos et al., 2021; Tena et al., 2021; Chen at al., 2021].

3) Mesophilic-thermophilic [Gianico et al., 2014; Vital-Jacome and Buitron, 2021]

4) Termophilic-Termophilic [Ramos et al., 2021; Chaikasem et al., 2014; Kovalev et al., 2021a; Kovalev et al., 2021b]]

5) Psychrophilic-psychrophilic $\left(21-1{ }^{\circ} \mathrm{C}\right)$ [Rusín et al., 2021)];

In [Parawira et al., 2007] three sets of temperature conditions (with different types of BRs as well) were investigated: (I) mesophilic + mesophilic, (II) mesophilic + thermophilic and (III) thermophilic + thermophilic with different optimal results concerning the yields of methane and DBD.

\section{2. $\mathrm{pH}$ and alkalinity}

Among all the chemical factors influencing dark fermentation, the $\mathrm{pH}$ is considered the most essential. It influences the stability of the acidproducing fermentative bacteria and acetoclastic $\mathrm{CH}_{4}$-producing archaea. $\mathrm{Ph}$ plays a major role in the oxidation-reduction potential of the anaerobic process. Thus, it directly impacts the metabolic pathway. In most of literature reports, a $\mathrm{pH}$ of 5.5 
has been considered to be the optimum $\mathrm{pH}$ for $\mathrm{H}_{2}$ production [Hawkes et al.,2002; O-Thong et al., 2008; Hawkes et al, 2007;., Cai et al., 2010]. The optimal initial $\mathrm{pH}$ range for the maximum $\mathrm{H}_{2}$ yield or specific $\mathrm{H}_{2}$ production rate is between $\mathrm{pH} 5.5$ and 6.5 [Cai et al., 2010]. The optimal pH is highly dependent on the microorganisms. The control of $\mathrm{pH}$ and alkalinity of a substrate is essential for first stage dark fermentation since organic acids produced tend to decrease the $\mathrm{pH}$. The $\mathrm{pH}$ lower than 4.5 trends to inhibit the activity of hydrogeneses. Low $\mathrm{pH}$ also causes in shift of metabolic pathways of dark fermentation microorganisms away from $\mathrm{H}_{2}$ production. $\mathrm{H}_{2}$-producing bacteria like Clostridium acetobutylicum can change metabolism from $\mathrm{H}_{2}$ (acetate and butyrate pathway) to the production of solvents (acetone and butanol pathway) when the $\mathrm{pH}$ is decreased to less than $5.0 \%$. Alternatively, depending on the organism, low $\mathrm{pH}$ can shift the metabolism toward ethanol production [Li and Fang, 2007]. $\mathrm{CH}_{4}$ production is favored at alkaline $\mathrm{pH}$ exhibiting maximum activity at $\mathrm{pH}$ of $7.8-8.2$ [Deublein, and Steinhauser, 2008].

The rate of $\mathrm{CH}_{4}$ production may decrease if the $\mathrm{pH}$ is lower than this optimal range. The $\mathrm{pH}$ is also an important factor for the stability of $\mathrm{CH}_{4}$ production. The $\mathrm{H}_{2}$ effluent which is rich in VFAs, may cause a drop in $\mathrm{pH}$ if fed with high OLR. The $\mathrm{pH}$ adjustment can be achieved by an addition of alkali chemical, typically calcium carbonate or sodium hydroxide. A cheap material like ash was used to adjust the $\mathrm{pH}$ in an anaerobic reactor [Lo et al, 2009].

\section{ANOTHER PROCESS PARAMETERS AFFECTING BIOHYTHANE PRODUCTION}

\subsection{Inoculums}

The choice of the inoculum is a fundamental step for the good performance of the AD process. The use of sludge from digesters or treatment ponds for the degradation of residues of similar characteristics to the substrates of interest makes the systems more efficient and more adapted (Jeihanipour et al., 2011) and may considerably reduce the lag phase time (Yang et al., 2015), especially in more complex systems. Ma et al. (2021) reviewed the literature seeking to quantitatively correlate the production of methane with the abundance of microbiota in anaerobic digestion processes.

Developing an enriched inoculum is very important for obtaining $\mathrm{H}_{2}$ in first stage fermentation. In the enrichment process, selection procedure was applied to selectively promote $\mathrm{H}_{2}$-producing bacteria and eliminate $\mathrm{H}_{2}$ consumers.

\subsection{Hydrogen partial pressure}

The $\mathrm{H}_{2}$ partial pressure in the liquid phase is the major factor affecting $\mathrm{H}_{2}$ production, as high $\mathrm{H}_{2}$ partial pressure causes deactivation of hydrogenase enzyme.

\subsection{Hydraulic retention time (HRT)}

The total time that cells and soluble nutrients reside in the reactor is called the HRT. $\mathrm{H}_{2}$ production occurring at low HRT is dependent on the volume of the reactor and the flow rate of feed. It is generally well known that the $\mathrm{H}_{2}$-producing bacteria are fast growing. By applying this principle, [Liu et al., 2019] produced $\mathrm{H}_{2}$ free of $\mathrm{CH}_{4}$ in continuously CSTR feeding with household solid waste at acidic $\mathrm{pH}$ range of 5.0-5.5 and a short HRT of 3 days $\left(D=0.33\right.$ day $\left.^{-1}\right)$ without any pretreatment to inhibit methanogens contained in the initial digested manure.

HRT is the main optimization parameters of continuous $\mathrm{H}_{2}$ dark fermentation bioprocesses. In the CSTRs, short HRTs or high dilution (D) rates can be used to eliminate methanogens, which have significant low growth rate [Hawkes et al., 2007; Kyazze et al., 2007]. However, HRT is needed to be maintained in a proper level that still gives a $\mathrm{D}$ value less than specific growth rate of $\mathrm{H}_{2-}$ producing bacteria. Generally, short HRT is considered to favor the $\mathrm{H}_{2}$ fermentation metabolism [Hawkes, 2002]. On the other hand, too high loading rates may result in substrate inhibition effects, improper food to microorganism (F/M) ratios of $\mathrm{H}_{2}$ producers or washout of microorganisms [Lay, 2001].

In second stage, the HRT is a measure to describe the average time that a certain substrate resides in a digester. If the HRT is shorter, the system will fail due to washout of microorganisms. HRT for anaerobic digestion process are typically in the range of 15-30 days at mesophilic conditions and 10-20 days at thermophilic conditions [Mamimin et al.,2015].

\section{4. $\mathrm{C} / \mathrm{N}$ ratio}

The carbon found in the degradable organic structures, is extremely important for the digestion process, being used directly in the generation of methane molecules, while the nitrogen (mainly from proteins) is a fundamental element in the formation of the bacterial cells involved in the whole process. Therefore, a balance between carbon and nitrogen 
concentrations is fundamental for the $\mathrm{AD}$ process. Ideal $\mathrm{C} / \mathrm{N}$ ratios are between 20 and 35 (Weiland, 2006; Khalid et al., 2011). Higher C/N ratios may limit the inoculum renewal and new cell formation, while very low ratios (high amount of nitrogen as ammonium concentrations) may increase environmental toxicity to the microorganisms of interest (Esposito et al., 2012; Rocamora et al., 2020). Both conditions are detrimental to biogas production. Mixing substrates of different properties may help in equalizing these essential elements. In addition, a good control and $\mathrm{pH}$ stability might ensure a reduction in ammonia toxicity in the reactors (Yao et al., 2020).

\subsection{Trace elements}

Biohydrogen and biomethane production required various types of metal ions as micronutrients. These metal ions play a critical role in the metabolism of microorganisms. Metal ions such as $\mathrm{Fe}^{2+}, \mathrm{Zn}^{2+}, \mathrm{Ni}^{2+}, \mathrm{Na}^{+}, \mathrm{Mg}^{2+}$, and $\mathrm{Co}^{2+}$ play a pivotal role in both biohydrogen and biomethane process. Metals are essential to supplement in media for dark fermentation. These micronutrients might be required in trace amounts but they have an influential role as cofactors, transport processes facilitators, and structural skeletons of many enzymes (Fe-Fe hydrogenase and $\mathrm{Ni}-\mathrm{Fe}$ hydrogenase) involved in the biochemistry of $\mathrm{H}_{2}$ formation [Romero-Güiza, 2016]. Therefore, several researchers have studied the effect of supplementation of $\mathrm{Fe}$ ion on biohydrogen production. [Hussy et al., 2005] performed a detailed analysis of the effectiveness of trace elements (such as $\mathrm{Mg}, \mathrm{Na}, \mathrm{Zn}, \mathrm{K}, \mathrm{I}, \mathrm{Mn}, \mathrm{NH}_{4} \mathrm{Ni}, \mathrm{Ca}, \mathrm{Cu}$ and $\mathrm{Mo}$ ) for microorganism life processes. Magnesium is the most important nutrient, followed by sodium, zinc and iron. The presence of iron in certain concentrations is an essential element for the reproduction and activity of bacteria, considering that most of the enzymes involved. Parameters Affecting HPB Activity 19 in hydrogen production contain iron-sulfur clusters, as previously described; the increase in sulfate at $3,000 \mathrm{mg} \mathrm{S_{4 }} 2-\mathrm{L}-1$ inhibits the production of hydrogen, due to a change in the metabolic pathway towards butyrate and ethanol.

5.6. Recirculation of the effluent of a methanogenic reactor

Recirculation of the effluent of a methanogenic reactor (digestate) is often used as an option instead of dosing alkali to raise the $\mathrm{pH}$ in the hydrogen producing bioreactor and control it at a fairly high level of 5.5, which is considered optimal for microorganisms that produce hydrogen and has an inhibitory effect on hydrogen scavengers, mainly on methanogenic archaea [Kovalev A.A. et al., 2021].

Our own studies concern TSAD of corn steep liquor (CSL) with simultaneous $\mathrm{H}_{2}$ and $\mathrm{CH}_{4}$ production in pilot scale biogas plant with automatic control system [Chorukova et al., 2021]. As a substrate in the $\mathrm{AD}$ process with hydrogen production used CSL - a waste product from the process of processing corn grain to extract starch. The corn extract was provided by "ADM Razgrad EAD" (Bulgaria).

All experiments were conducted in two connected bioreactors. First one with work volume of $10 \mathrm{dm}^{3}$ (for $\mathrm{H}_{2}$ production), second one with $80 \mathrm{dm}^{3}$ (for $\mathrm{CH}_{4}$ production), the ratio $\mathrm{V}_{2} / \mathrm{V}_{1}=10$. Initial experiments as well as inoculum maintenance was carried out in two laboratory scale bioreactors each one with work volume of 1 $\mathrm{dm}^{3}$ and $2 \mathrm{dm}^{3}$. In all experiments mesophilic temperature was maintained $\left(35^{\circ} \mathrm{C}\right)$ and continuous stirring mode. As an inoculum the liquid fraction from anaerobic digestor operating at mesophilic conditions was used.

\section{MICROBIOLOGY}

The microbiome residing in anaerobic digesters drives the $\mathrm{AD}$ process to convert various feedstocks to biogas as a renewable source of energy. This microbiome has been investigated in numerous studies in the last century [Lim et al., 2020; Hailu et al., 2021; Gallardo-Altamirano et al., 2021; Shia at al., 2021; Sposob et al., 2021]. Most of the feedstocks used for biogas production, such as livestock manure, crop residues (mainly lignocellulosic), and municipal sludge, are complex and rather recalcitrant to microbial hydrolysis, the rate-limiting step inherent of these feedstocks. To achieve efficient $\mathrm{AD}$, a diverse microbiome is required [Hassa et al., 2018]. The anaerobic digestion of renewable biomass is a microbial process wherein a community of fermentative and acetogenic bacteria together with acetoclastic and hydrogenotrophic methanogens convert organic matter into $\mathrm{CO}_{2}$ and $\mathrm{CH}_{4}$ [Liu et al., 2008]. The investigation of microbial communities basically includes the study of the community as a whole operating under as close to the in situ conditions as possible and the study of the constituent functional groups of microorganisms as interacting components [Kotsyurbenko, 2005]. 
When involving cellulose-containing substrates, the species that degrade cellulose belong mainly to the genera Cytophaga, Cellulomonas, Cellvibrio, Bacillus, Clostridium and Sporocytophaga [Szostak-Kotowa, 2004]. The strictly anaerobic, thermophilic bacterium Ruminiclostridium thermocellum is the microorganism with the fastest documented growth rate on the recalcitrant substrate crystalline cellulose [Lynd et al., 2002]. These organisms achieve a remarkable ability by forming very large extracellular multi-enzyme complexes, known as cellulosomes. Similar complexes are formed by related Clostridia (such as Clostridium acetobutylicum, Clostridium cellulolyticum, Clostridium cellulovorans, Clostridium josui and Clostridium papyrosolvens) and other anaerobic cellulose-degrading bacteria, such as Acetivibrio cellulolyticus, Pseudobacteroides cellulosolvens and Ruminococcus albus [Bayer et al., 2008]. Molecular biology techniques overcame the limitations of cultivation-based methods and allowed the identification of unculturable microorganisms, revealing the high diversity of microorganisms involved in AD. Several methods had been applied to investigate this microbial diversity, where in recent years methagenomics appears most efficient for determining the complex microbiota structure. In recent studies of $\mathrm{AD}$ processes was proved that the degradation is most probably due to the presence of members of genera Clostridium, Bacteroides and Ruminiclostridium. Among them, the most spread species are Clostridium butyricum, Bacteroides oleiciplenus and Ruminiclostridium papyrosolvens [Najdenski et al., 2020]. According to Wang et al., 2016 [Wang, et al.,2016] Bacteroidetes, Firmicutes and Protebacteria were the most abundant phyla, which were over $60 \%$ of the total relative abundance in two-phase systems and over 40\% in single-phase, while all detected Archaea belonged to class Methanomicrobia of the phylum Euryarchaeota, which were known as methanogenic microorganisms. In many studies the microbial community analysis provided crucial information to understand the anaerobic digestion process which may help to improve its efficiency [Rivière et al., 2009; Maspolim, et al., 2015; Xu, et al., 2018; Gao, et al., 2021].
The TSAD process is based on the differences between acidogens and methanogens in physiology, nutrition needs, growth kinetics, and sensitivity to environmental conditions. The acidogens and methanogens are enriched separately in two tanks enabling optimized growth by maintaining proper environmental conditions in each reactor [Demirel and Yenigün, 2002]. Microorganisms involved in the first stage $\mathrm{H}_{2}$ production and in the second stage $\mathrm{CH}_{4}$ production via two-stage anaerobic fermentation process are shown in Table 1.

The digester design and process need to reach the most favorable conditions, taking into account the differences between the vital conditions of hydrogen-consuming bacteria (HCB) and hydrogen-producing bacteria (HPB). The best operating conditions permit the inhibition of $\mathrm{HCB}$ and thus allow HPB to become the dominant population. The differences currently known between HCB and HPB concern their resistance to temperature, the extreme environmental conditions and the different growth rate of each species [Ruggeri, et al, 2015]. Bacteria belonging to the genus Clostridium are the main ones responsible for $\mathrm{H}_{2}$ production. They are obligate anaerobes, Gram-positive and rod-shaped. Clostridium sp. have a substantial characteristic that distinguishes them from other bacteria allowing the production of biohydrogen in anaerobic processes instead of biomethan: they are capable of producing protective end spores by undergoing a process called sporulation. This occurs when bacteria are exposed to harsh environmental conditions for bacterial growth. To be precise, endospores are metabolically inactive dormant bodies, like seeds, which wait until the environment again becomes favorable to life. Once environmental conditions change, the endospores germinate back into living vegetative cells that can grow and thrive. In extremely restrictive conditions, the spores might be very resistant and not easily destroyed, as opposed to HCB that are methanogens without such an ability to resist [Brock et al.,1994]. It happens in a specific case, in fact, that when the Clostridium spores are placed in favorable conditions, with nutrients and anaerobic conditions, the germination and metabolism processes can restart [Stanier et al., 1986], and consequently hydrogen and other metabolic products can be produced. 
Table 1. Microorganisms involved in the first stage $\mathrm{H}_{2}$ production, and the second stage $\mathrm{CH}_{4}$ production via two-stage anaerobic fermentation process [O-Thong et al., 2018]

\begin{tabular}{|c|c|c|c|}
\hline Stages & $\begin{array}{l}\text { Mesophilic condition } \\
\left(30-35^{\circ} \mathrm{C}\right)\end{array}$ & $\begin{array}{l}\text { Thermophilic condition } \\
\left(55-60^{\circ} \mathrm{C}\right)\end{array}$ & $\begin{array}{l}\text { Extreme thermophilic } \\
\text { condition }\left(70-90^{\circ} \mathrm{C}\right)\end{array}$ \\
\hline $\begin{array}{l}1^{\text {st }} \text { hydrogen } \\
\text { production } \\
\text { (Bacteria) }\end{array}$ & $\begin{array}{l}\text { Clostridium sp. } \\
\text { Enterobacter sp. } \\
\text { Citrobacter sp. } \\
\text { Bacillus sp. }\end{array}$ & $\begin{array}{l}\text { Thermoanaerobacterium sp. } \\
\text { Clostridium sp. } \\
\text { Thermoanaerobacter sp. }\end{array}$ & $\begin{array}{l}\text { Caldanaerobacter sp. } \\
\text { Caloramator sp. } \\
\text { Thermotoga sp. }\end{array}$ \\
\hline $\begin{array}{l}2^{\text {nd }} \text { methane } \\
\text { production } \\
\text { (Bacteria) }\end{array}$ & $\begin{array}{l}\text { Clostridium sp. } \\
\text { Bacillus sp. } \\
\text { Desulfobacterium sp. }\end{array}$ & $\begin{array}{l}\text { Clostridium sp. } \\
\text { Thermoanaerobacterium sp. } \\
\text { Desulfomicrobium sp. }\end{array}$ & Caloramator sp. \\
\hline $\begin{array}{l}2^{\text {nd }} \text { methane } \\
\text { production } \\
\text { (Archaea) }\end{array}$ & $\begin{array}{l}\text { Methanobacterium sp. } \\
\text { Methanoculleus sp. } \\
\text { Methanospirillum sp. } \\
\text { Methanococcus sp. } \\
\text { Methanobacter sp. }\end{array}$ & $\begin{array}{l}\text { Methanothermobacter sp. } \\
\text { Methanosarcina sp. }\end{array}$ & $\begin{array}{l}\text { Methanothermus sp. } \\
\text { Methanothermococcus sp. }\end{array}$ \\
\hline
\end{tabular}

Enterobacter sp. are also $\mathrm{H}_{2}$-producing microorganisms with the advantage that they are facultative bacteria able to grow in the presence of oxygen. Based on phylogenetic analysis of the rDNA sequences, Fang et al. 2002 found that $64.6 \%$ of all the clones were affiliated with three Clostridium species, $18.8 \%$ with Enterobacteriaceae and $3.1 \%$ with Streptococcus bovis (Streptococcaceae). The remaining $13.5 \%$ belonged to eight operational taxonomic units whose affiliations were not identified. Methanogens play a vital ecological role in anaerobic environments by removing excess hydrogen and fermentation products yielded by acetogenic bacteria, producing methane. Methanogens are usually coccoid rods or rod-shaped bacteria. There are over 50 described species of methanogens, which do not form a monophyletic group, although all of them belong to the Archaea. Methanogens are strict anaerobes and when they are exposed to an aerobic environment, the oxygen lowers their adenylate charge and causes their death [Oremland, 1988]. The physiological differences between HPB (also called acidogenic bacteria) and HCB (methanogens, Archaea and homoacetogenic bacteria) are the basis of the scientific rationale behind the development of the various methods proposed to prepare hydrogenproducing seeds [Zhu et al., 2006].

The following list summarizes the main differences between HPB and HCB:

- Most methanogens are limited to a relatively narrow $\mathrm{pH}$ range (about 7-8) [Oremland, 1988], while most HPB can grow over a broader $\mathrm{pH}$ range (4.5-7) [Zhu et al., 2006].
- HPB have much faster growth kinetics than HCB.

- HPB are able to resist harsh environmental conditions due to protective spore formation, while HCB are very sensitive and do not have this capacity.

In our own research several methods had been applied to investigate their microbial diversity: clone library of 16S rRNA genes, denaturing gradient gel electrophoresis (DGGE) analysis, fluorescence in situ hybridization (FISH), etc. Metagenomics is an efficient method for determining the complex microbiota structure and performing metabolic mechanism analysis. It is applied for elucidation of community structure and metabolic pathway analysis to determine the mechanism of cellulose degradation in natural consortia.

\section{MATHEMATICAL MODELLING}

A lot of models describing separately the fermentative $\mathrm{H}_{2}$ production [Nasr et al., 2013; Wang and Wan, 2009, 34, 3313-23] and the AD for $\mathrm{CH}_{4}$ production [Batstone et al., 2002; Dochain and Vanrolleghem, 2001, Wade, 2020] are known. However, only few models of the TSAD process are known from the available literature [Blumensaat and Keller, 2005; Rodriguez et al., 2013; Donoso-Bravo et al., 2019; Kamyab and Zilouei; 2021].

Our team developed mathematical models of the TSAD processes started from simple models [Simeonov and Chorukova, 2016; Chorukova et al., 2016; Diop et al., 2017; Chorukova and Simeonov, 2020]. They are useful for software sensors and automatic control algorithms design. 
Some of our models were developed on the base of the well known mathematical model of IWA ADM1 [Borisov et al., 2016; Borisov et al. (a), 2020; Borisov et al. (b), 2020]. They are useful for theoretical studies and optimization of the TSAD processes using computer simulations.

For exemple the so called "static characteristic" may be obtained analytically or by simulations (Fig. 2, Fig. 3).

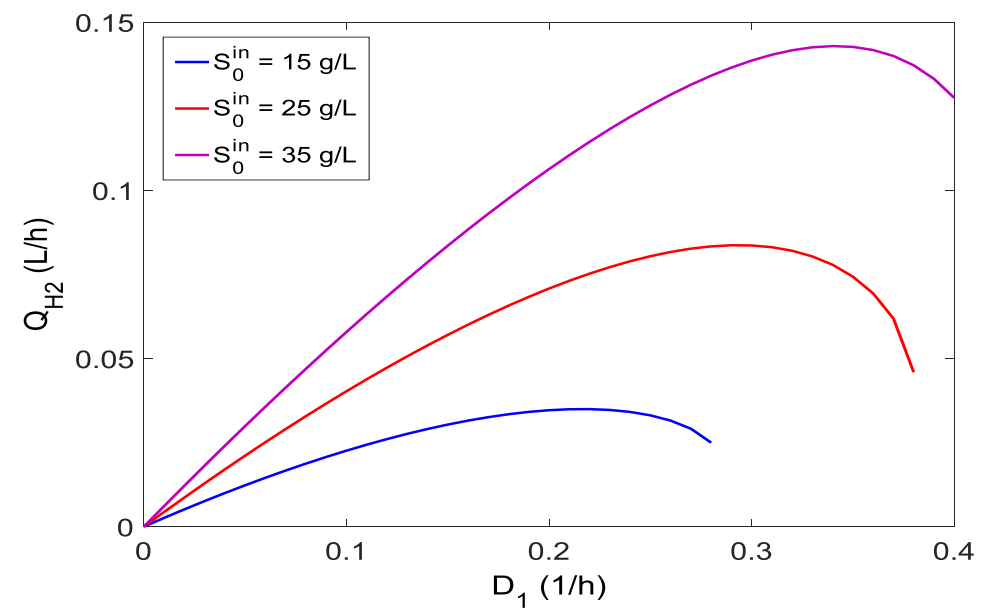

Fig. 2. Input-output static characteristic $Q_{\mathrm{H} 2}=f\left(D_{1}\right)$ of $\mathrm{BR}_{1}$,

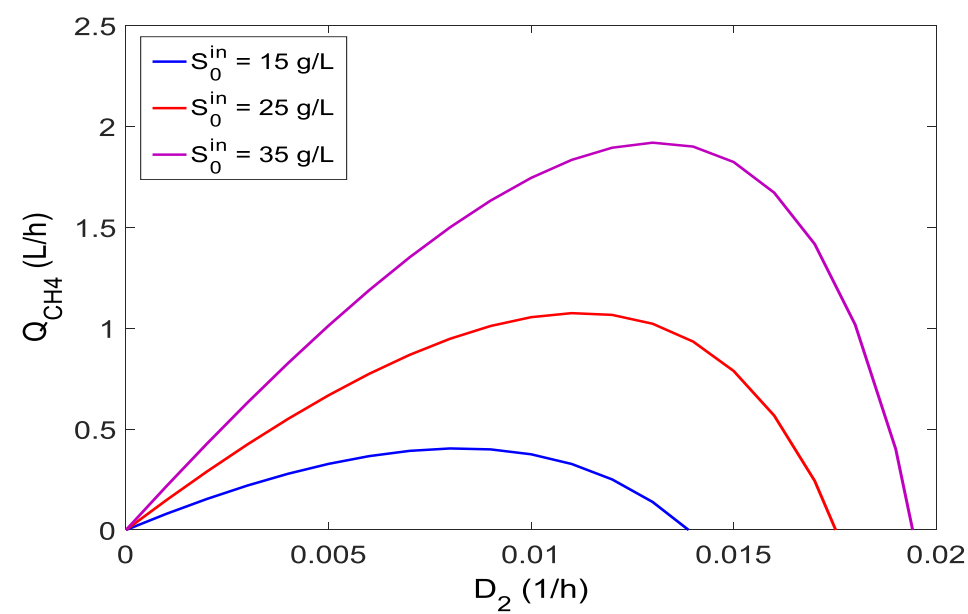

Fig. 3. Input-output static characteristic $Q_{\mathrm{CH} 4}=f\left(D_{2}\right)$ of $\mathrm{BR}_{2}$

From Fig. 2 and Fig. 3 is evident that a maximum of biogas yield exists for both BRs (for biohydrogen and for biomethane). That is the base for application of the so called "extremum seeking control".

In the known literature more of the TSAD processes are operated manually and the ratio of working volume of CSTR bioreactors is not discussed. In some reports a ratio of 10 is accepted without comments [Gómez Camacho et al., 2019]. According to Dareioti and Kornaros [Dareioti et al., 2014] a TSAD system consisting of two CSTRs operating at mesophilic conditions was used to investigate the effect of hydraulic retention time (the reciprocal value of the dilution rate) on $\mathrm{H}_{2}$ and $\mathrm{CH}_{4}$ production. The ratio of working volumes of bioreactors is equal of 8 (without comments). Cavinato et al. [Cavinato et al., 2011] performed optimization of TSAD with separately collected municipality biowaste in a pilot scale CSTRs at thermophilic regime using recirculation of the digestate of the second $\mathrm{BR}$ to maintain the $\mathrm{pH}$ in the $\mathrm{BR}_{1}$ at the optimal value. The ratio of working volumes of bioreactors is equal of 3.8. Optimal loading rate is obtained providing maximum $\mathrm{H}_{2}$ and $\mathrm{CH}_{4}$ productions in TSAD of cassava wastewaters using specific thermophilic bioreactors and constant recycling ratio of $1: 1$ 
with automatic control of $\mathrm{pH}$ in the hydrogenic bioreactor in the report [Intanoo et al., 2014]. The ratio of working volumes of both bioreactors is equal of 6 (without explanation). In the work [Schievano et al.,2014] both bio-hydrogen and bio-methane productions are optimised in thermophilic bioreactors regarding two operating parameters (organic loading rate and dilution rate), however, the first bioreactor is running in semi-continuous and the second - in batch operation mode, because working volumes of both bioreactors are equal. The first review article [Khan et al., 2016] combines the optimization approaches for three possible products from AD $\mathrm{H}_{2}, \mathrm{CH}_{4}$, and VFAs, taking into account different process parameters and types of $\mathrm{BR}$, including acidogenesis and methanogenesis separation in two different BRs. However, the ratio of working volumes of the BRs is not included and discussed.

In the TSAD processes an important from technological and economical point of view problem exists - how do determine the ratio of the working volumes of the $\mathrm{H}_{2}$ and $\mathrm{CH}_{4}$ producing BRs for optimization of all processes. In [Buback dos Santos et., 2021; Ganesh et al., 2014] possible solutions of this problem are presented in view of maximizing the energy production (the produced $\mathrm{H}_{2}$ and $\mathrm{CH}_{4}$ ). Our team [Chorukova et al., 2021] proposed a solution of this problem for CSTR on the base of the developed mathematical models.

\section{ENERGETICAL CONSIDERATIONS}

To meet the increased demand for energy needs and to reduce greenhouse gas emissions, the capacity of worldwide installed renewable energy systems has been doubled over the last decade [Nsair, et al., 2020]. This also applies to biogas as a source of renewable energy, where the number of biogas plants installed in Europe has been increased from 6227 in 2009 to reach 18202 by the end of 2018 [Sevillano et al., 2021]. The total produced electricity from biogas reached $88 \mathrm{TWh}$ in 2017, 40\% of which was generated in Germany [Sevillano et al., 2021]. Hence, Germany is a leading country in this field. Due to more than 9000 large-scale $\mathrm{AD}$ plants, biogas technology is making a significant contribution to the sustainable energy supply in Germany [Weinrich and Nelles, 2021]. With a total of around $5901 \mathrm{MW}_{\mathrm{el}}$ of installed electrical capacity (on-site electricity generation), electricity generated from biogas amounted to around 31.6 TWh in 2019 and thus accounts for over $58 \%$ of total electricity generation from biomass. In Germany, anaerobic digestion plants usually use renewable raw materials and animal excrements (manure and dung) to operate.

Our experimental results are summarized from energetical point of view in Table 2 [Simeonov et al., 2021].

Table 2. Experimental results obtained during the TFAD continuous tests

$$
\left(\gamma=\mathrm{V}_{1} / \mathrm{V}_{2}=0.1 \text { and } \mathrm{S}_{0 \mathrm{i}}=50 \mathrm{~g} / \mathrm{L}\right) \text {. }
$$

\begin{tabular}{lc}
\hline Hydraulic retention time for $\mathrm{H}_{2}$ reactor (days) & 2.5 \\
Dilution rate $\mathrm{D}_{1}($ days & -1 \\
Hydraulic retention time for $\mathrm{CH}_{4}$ reactor (days) & 0.4 \\
Dilution rate $\mathrm{D}_{2}($ days & -1 \\
Hydrogen production $\left(\mathrm{dm}^{3} \mathrm{~L}^{-1} \mathrm{day}^{-1}\right)$ & 25 \\
Methane production $\left(\mathrm{dm}^{3} \mathrm{~L}^{-1} \mathrm{day}^{-1}\right)$ & 0.04 \\
Total energy production $(\mathrm{kWh} /$ day) & 0.241 \\
\hline
\end{tabular}

Our experiments for TFAD of corn steep liquor are in the initial phase of technology development and were at low organic loads on both BRs.

Other representative results [Ruggeri, et al., 2015] for TFAD of organic wastes are presented in Table 3, where the operative conditions for the continuous tests, the specific $\mathrm{H}_{2}$ and $\mathrm{CH}_{4}$ production (mean value), the total energy harvest by TFAD and the efficiency values are given.

The efficiency can be evaluated as: $\eta=$ Produced energy $\left(\mathrm{H}_{2}+\mathrm{CH}_{4}\right) /$ Initial energy embedded in the substrate x $100(\%)$. 
Table 3. Experimental conditions and results for the TFAD continuous tests $(\gamma=0.1)$.

\begin{tabular}{lccc}
\hline Hydraulic retention time for $\mathrm{H}_{2}$ reactor (days) & 0.25 & 1 & 1.5 \\
Dilution rate $\mathrm{D}_{1}\left(\right.$ days $\left.^{-1}\right)$ & 4 & 1 & 0.667 \\
Hydraulic retention time for $\mathrm{CH}_{4}$ reactor (days) & 2.5 & 10 & 15 \\
Dilution rate $\mathrm{D}_{2}\left(\right.$ days $\left.^{-1}\right)$ & 0.4 & 0.1 & 0.0667 \\
$\mathrm{H}_{2}$ production $\left(\mathrm{L} \mathrm{L}^{-1}\right.$ day $\left.^{-1}\right)$ & 1.67 & 0.49 & 0.19 \\
$\mathrm{CH}_{4}$ production $\left(\mathrm{L} \mathrm{L}^{-1} \mathrm{day}^{-1}\right)$ & 4.52 & 1.31 & 0.99 \\
Total energy production $(\mathrm{kWh} /$ day) & 0.0004997 & 0.14472 & 0.108 \\
Efficiency $\eta(\%)$ & 49 & 56 & 63 \\
\hline
\end{tabular}

\section{CONCLUSIONS}

Methane is being commonly used, not only in the chemical industry but also in transport as compressed natural gas, which has been regarded as the clean energy carrier in comparison to gasoline or diesel. However, by combining the advantages of $\mathrm{H}_{2}$ and $\mathrm{CH}_{4}$, biohythane is considered one of the important fuels involved in achieving the transition of technical models from a fossil fuel-based society to renewable-based society. In addition to economical concern, the TSAD process has been previously evaluated that the payback time is around 2-6 years, depending on the disposal costs of organic wastes/residues [Wang and Zhao, 2009].

Various types of organic wastes can be used as substrate for biohythane production.

Biohythane via TSAD of organic waste could be a promising technology for higher energy recovery and a cleaner transport biofuel than the biogas. The $\mathrm{H}_{2} / \mathrm{CH}_{4}$ ratio of range $0.1-0.25$ is suggested for biohythane.

The TSAD could increase DBD, net energy balance, $\mathrm{CH}_{4}$ production rates as well as high yield and purity of the products. In addition, the TSAD process has advantages of improving negative impacts of inhibitive compounds in feedstock, increased reactor stability with better control of the acid production, higher organic loading rates operation, and significantly reducing the processes time.

ACKNOWLEDGEMENTS: This study is funded by the Bulgarian National Science Fund under contract КП-06-H46/4 "Experimental studies, modeling and optimal technologies for biodegradation of agricultural waste with hydrogen and methane production".

\section{REFERENCES}

1. Achinas S., V. Achinas, E.G. Euverink, A Technological Overview of Biogas Production from Biowaste, Engineering, Vol. 3, 2017, 299-307.

2. Ariunbaatar J., E.S. di Perta, A. Panico, L. Frunzo, G. Esposito, P.N.L. Lens, F. Pirozzi, Effect of ammoniacal nitrogen on one stage and two-stage anaerobic digestion of food waste, Waste Management, Vol. 38, 2015, 388-398.

3. Aruna Devi P.S., M. Saravanaraja, K. Nagarajan, Efficiency of two phase UASB reactor with internal packing column for the treatment of dairy effluent, Global Journal of Engineering Science and Researches, Vol. 5(7), 2018, 400-419.

4. Athanasoulia E., P. Melidis, A. Aivasidis, Optimization of biogas production from waste activated sludge through serial digestion, Renewable Energy, Vol. 47, 2012, 147-151.

5. Ausiello A. et al., Biohydrogen production by dark fermentation of Arundo donax using a new methodology for selection of H2-producing bacteria, Int. J. Hydrogen Energy, Vol. 42, 2017, 30599-30612.

6. Bakonyi P., J. Dharmaraja, S. Shobana, L. Kook, T. Rozsenberszki, N. Nemestothy, R. Banu J, K. Belafi-Bako, G. Kumar, Leachate valorization in anaerobic biosystems: Towards the realization of waste-to-energy concept via biohydrogen, biogas and bioelectrochemical processes, Int. J. Hydrogen Energy, Vol. 44(32), 2019, 17278-17296.

7. Baldi F., I. Pecorini b, R. Iannelli, Comparison of single-stage and two-stage anaerobic co-digestion of food waste and activated sludge for hydrogen and methane production, Renewable Energy, Vol. 143, 2019, 1755-1765.

8. Bayer E.A, R. Lamed, B. A. White, H. J. Flint, From cellulosomes to cellulosomics, Chem. Rec., Vol. 8(6), 2008, 364-377. 
9. Bo W., L. Wenhui, Progress of research on twophase anaerobic fermentation of hydrogen production and methanogenesis, Chemical Engineering Transactions, Vol. 64, 2018, 337-342.

10. Bolzonella D., F. Battista, C. Cavinato, M. Gottardo, F. Micolucci, G. Lyberatos, P. Pavan, Recent developments in biohythane production from household food wastes: a review, Bioresour. Technol., Vol. 257, 2018, 311-319.

11. Borisov M., D. Denchev, I. Simeonov (a), Mathematical modelling of a two-stage anaerobic digestion process with hydrogen and methane production using ADM1, Ecological Engineering and Environment Protection, Vol. 1, 2020, 18-29.

12. Borisov M., N. Dimitrova, I. Simeonov (b), Mathematical Modelling and Stability Analysis of a Two-phase Biosystem, Processes, Vol. 8(7), 2020, 791.

13. Borisov M., N. Dimitrova, I. Simeonov, Mathematical Modelling of Anaerobic Digestion with Hydrogen and Methane Production, Prep. of the 6th IFAC Conference on Foundations of Systems Biology in Engineering, The International Federation of Automatic Control, Magdeburg, Germany, October 912, 2016, (TuPP.2: 1-8), IFAC-PapersOnLine, Vol. 49(26), 2016, 231-238.

14. Bradford M.M., A rapid and sensitive method for the quantitation of microgram quantities of protein utilizing the principle of protein-dye binding, Anal Biochem., Vol. 72, 1976, 248-254.

15. Brock T.D., M.T. Madigan, J.M. Martino, J. Parker, Biology of microrganisms, Prentice-Hall, New York, 1994.

16. Bubark dos Santos S., M.O. Faber, A.C.A. Collacoc, E.C.G. Aguieiras, D.M.G. Freire, M.A.P. Langone, V.S. Ferreira-Leitao, Sequential hydrogen and methane production using the residual biocatalyst of biodiesel synthesis as raw material, International journal of hydrogen energy, Vol. 46, 2021, 2365823669.

17. Camacho C.E.G., B. Ruggeri, L. Mangialardi, M. Persico, A.C.L. Malavé, Continuous two-step anaerobic digestion (TSAD) of organic market waste: rationalising process parameters, International Journal of Energy and Environmental Engineering, Vol. 10, 2019, 413-427.

18. Chaikasem S., P. Jacob, C. Visvanathan, Performance improvement in a two-stage thermophilic anaerobic membrane bioreactor using PVA-gel as biocarrier, Desalination and Water Treatment, Vol. 53(10), 2015, 1-11.

19. Chatterjee B., D. Mazumder, Performance evaluation of three-stage AD for stabilization of fruit and vegetable waste, J. Indian Chem. Soc., Vol. 95, 2018, 65-80.

20. Chen H., W. Zhang, J. Wu, X. Chen, R. Liu, Y. Han, B. Xiao, Z. Yu, Y. Peng, Improving two-stage thermophilic-mesophilic anaerobic co-digestion of swine manure and rice straw by digestate recirculation, Chemosphere, Vol. 274, 2021, 129787.

21. Chorukova E., I. Simeonov, L. Kabaivanova, Optimizing the ratio of working volumes of bioreactors in a two-stage anaerobic digestion system for production of hydrogen and methane, ECOL CHEM ENG S., Vol. 28(2), 2021, 183-200.

22. Chorukova E., I. Simeonov, Mathematical modeling of the anaerobic digestion in two-stage system with production of hydrogen and methane including three intermediate products, Int. J. Hydrog. Energy, Vol. 45, 2020, 11550-11558.

23. Chorukova E., I. Simeonov, Mathematical modeling of the anaerobic digestion in two-stage system with production of hydrogen and methane including three intermediate products, Int. J. Hydrog. Energy, 2020, Vol. 45, 11550-11558.

24. Chorukova E., V. Hubenov, L. Kabaivanova, Y. Gocheva and I. Simeonov, Two-phase anaerobic digestion of corn steep liquor, Ecological Engeneering and Environment protection, Vol. 4, 2020, 75-84.

25. Chorukova E., V. Hubenov, L. Kabaivanova, Y. Gocheva, I. Simeonov, Two-phase anaerobic digestion of corn steep liquor, Ecological Engineering and Environment Protection, Vol. 1, 2021, 75-84 (in Bulgarian).

26. Chow W.L, S. Chong, J.W. Lim, Y.J. Chan, M.F. Chong, T.J. Tiong, J.K. Chin, G.T. Pan, Anaerobic Co-Digestion of Wastewater Sludge: A Review of Potential Co-Substrates and Operating Factors for Improved Methane Yield, Processes, Vol. 8, 2020, 39 .

27. Chu C.F., K.Q. Xu, Y.Y. Li, Y. Inamori, Hydrogen and methane potential based on the nature of food waste materials in a two-stage thermophilic fermentation process, Int. J. Hydrog. Energy, Vol. 37, 2012, 10611-10618.

28. Chu Y.C., Z.F. Wang, Dairy cow solid waste hydrolysis and hydrogen/methane productions by anaerobic digestion technology, Int. J. Hydrogen Energy, Vol. 42, 2017, 30591-98.

29. Cremonez P.A., J.G. Teleken, T.R.W. Meier, H.J. Alves, Two-Stage anaerobic digestion in agroindustrial waste treatment:A review, Journal of Environmental Management, Vol. 281, 2021, 111854.

30. Cui F., S. Lee, M. Kim, Removal of organics and nutrients from food wastewater using combined thermophilic two-phase anaerobic digestion and shortcut biological nitrogen removal, Water Research, Vol. 45, 2011, 5279-5286.

31.D'Silva T.C., A. Isha, R. Chandra, V.K. Vijay, P. Mohan, V. Subbarao, R. Kumar, V.P. Chaudhary, H. Singh, A.A. Khan, V.K. Tyagi, K.L. Kovacs, Enhancing methane production in anaerobic digestion through hydrogen assisted pathways - A state-of-the- 
art review, Renewable and Sustainable Energy Reviews, Vol. 151, 2021, 111536.

32. Demirel B, O. Yenigün, Two-phase anaerobic digestion processes: A review, Journal of Chemical Technology and Biotechnology, Vol. 77, 2002, 743755.

33. Demirer G.N., S. Chen, Two-phase anaerobic digestion of unscreened dairy manure, Process Biochemistry, Vol. 40, 2005, 3542-3549.

34. Denchev D., V. Hubenov, I. Simeonov, L.Kabaivanova, Biohydrogen production from lignocellulosic waste with anaerobic bacteria, Proc. of the 4th International Conference on Water, Energy and Environment (ICWEE), Burgas, Bulgaria, June 1-3, 2016, 7-12.

35. Deublein D., A. Steinhauser, Biogas from waste and renewable resources, Publisher: Weinheim, 2008.

36. Diop S., E. Chorukova, I. Simeonov, Modeling and Specific Growth Rates Estimation of a Two-Stage Anaerobic Digestion Process for Hydrogen and Methane Production, IFAC-PapersOnLine, ELSEVIER, Vol. 50(1), 2017, 12641-12646.

37. Divya D., L.R. Gopinath, Christy, P.M., A review on current aspects and diverse prospects for enhancing biogas production in sustainable means, Renew. Sustain. Energy Rev., Vol. 42, 2015, 690-699.

38. Donoso-Bravo A., P. Gajrdo, M. Sebbah, D. Vicencio, Comparison of performance in an anaerobic digestion process: one-reactor vs two-reactor configurations, Mathematical Bioscience and Engineering, Vol. 16(4), 2019, 2447-2465.

39. Dung L., Y. Chen, Y. Xu, B. Hu, Improving treatment capacity and process stability via a two-stage anaerobic digestion of food waste combining solidstate acidogenesis and leachate methanogenesis/recirculation, Journal of Cleaner Production, Vol. 279, 2021, 123644.

40. Elbeshbishy E., B.R. Dhar, G. Nakhla, H.Y. Lee, A critical review on inhibition of dark biohydrogen fermentation, Renew. Sustain. Energy Rev., Vol. 79, 2017, 656-668.

41. Esposito G., L. Frunzo, A. Giordano, F. Liotta, A. Panico, F. Pirozzi, Anaerobic co-digestion of organic wastes, Rev. Environ. Sci. Biotechnol., Vol. 11(4), 2012, 325-341.

42.Fang H.H.P., T. Zhang, H. Liu, Microbial diversity of a mesophilic hydrogen-producing sludge, Appl. Microbiol. Biotechnol., Vol. 58, 2002, 112-118.

43. Forouzanmehr F., K. Solon, V. Maisonnave, O. Daniel, E.I.P. Volcke, S. Gillot, P. Buffierea, Sulfur transformations during two-stage anaerobic digestion and intermediate thermal hydrolysis, Science of the total environment, 2021, 151247, (in press).

44. Fuentes K.L., P. Torres-Lozada, T.R. Chaparro, Beverage wastewater treatment by anaerobic digestion in two-stages for organic matter removal and energy production, Biomass and Bioenergy, Vol. 154, 2021, 106260.

45. Gallardo-Altamirano M.J., P. Maza-Márquez, N. Montemurro, S. Pérez, B. Rodelas, F. Osorio, C. Pozo, Insights into the removal of pharmaceutically active compounds from sewage sludge by two-stage mesophilic anaerobic digestion, Science of The Total Environment, Vol. 789, 2021, 147869.

46. Ganesh R., M. Torrijos, P. Sousbie, A. Lugardon, J.-Ph. Steyer, Single-phase and two-phase anaerobic digestion of fruit and vegetable waste: Comparison of start-up, reactor stability and process performance, Waste Management, Vol. 34, 2014, 875885.

47. Gao M., B. Guo, L. Li, Y. Liu, Role of syntrophic acetate oxidation and hydrogenotrophic methanogenesis in co-digestion of blackwater with food waste, Journal of Cleaner Production, Vol. 283, $2021,125393$.

48. Gerardi M.H, The microbiology of anaerobic digesters, John Wiley\&Sons, Inc. New Jersey, 2003.

49. Gianico A., C.M. Braguglia, A. Galliapoli, G. Mininni, Innovative two-stage mesophilic/thermophilic anaerobic degradation of sonicated sludge: performances and energy balance, Envir Sci Pollut Res, June 2014.

50.Guo X.M. et al., Hydrogen production from agricultural waste by dark fermentation: a review, Int. J. Hydrogen Energy, Vol. 36, 2010, 10660-73.

51. Hailu A.M., S.G. Palani, S.L. Asfaw, T.A. Tegaye, Insight into microbial community diversity and composition of two-stage anaerobic digestion: Focusing methanogenic stage, Bioresource Technology Reports, Vol. 15, 2021, 100764.

52. Hassa J., I. Maus, S. Off, A. Puhler, P. Scherer, M. Klocke, A. Schluter, Metagenome, metatranscriptome, and metaproteome approaches unraveled compositions and functional relationships of microbial communities residing in biogas plants, Appl. Microbiol. Biotechnol., Vol. 102, 2018, 5045-5063.

53. Hassan G.K., R.J. Jones, J. Massanet-Nicolau, R. Dinsdale, M.M. Abo-Aly, F.A. El-Gohary, A. Guwy, Increasing $2-\mathrm{Bio}-(\mathrm{H} 2$ and $\mathrm{CH} 4)$ production from food waste by combining two-stage anaerobic digestion and electrodialysis for continuous volatile fatty acids removal, Waste Management, Vol. 129, 2021, 20-25.

54. Hawkes F.R., I. Hussy, G. Kyazze, R. Dinsdale, D.L. Hawkes, Continuous dark fermentative hydrogen production by mesophilic microflora: Principles and progress, International Journal of Hydrogen Energy, Vol. 32, 2007, 172-184.

55. Hawkes F.R., R. Dinsdale, D.L. Hawkes, I. Hussy, Sustainable fermentative hydrogen pro-duction: Challenges for process optimization, International Journal of Hydrogen Energy, Vol. 27, 2002, 1339-1347. 
56.Hou T., J. Zhao, Z. Lei, K. Shimizu, Z. Zhang, Addition of air-nanobubble water to mitigate the inhibition of high salinity on co-production of hydrogen and methane from two-stage anaerobic digestion of food waste, Journal of Cleaner Production, Vol. 314, 2021, 127942.

57.Hou T., J. Zhao, Z. Lei, K. Shimizu, Z. Zhang, Enhanced energy recovery via separate hydrogen and methane production from two-stage anaerobic digestion of food waste with nanobubble water supplementation, Science of The Total Environment, Vol. 761, 2021, 143234.

58. Hovorukha V., O. Havryliuk, G. Gladka, O. Tashyrev, A. Kalinichenko, M. Sporek, A. Dołhanczuk-Sródka, Hydrogen dark fermentation for degradation of solid and liquid food waste, Energies, Vol. 14, 2021, 1831.

59. Hubenov V.N., S.N. Mihaylova, I.S. Simeonov, Anaerobic co-digestion of waste fruits and vegetables and swine manure in a pilot-scale bioreactor, Bulg. Chem. Commun., Vol. 47, 2015, 788-792.

60. Hussy I., F.R. Hawkes, D. Dinsdale, D.L. Hawkes, Continuous fermentative hydrogen production from sucrose and sugarbeet, Int. J. Hydrogen Energy, Vol. 30, 2005, 471-483.

61. Iglesias R., R. Muñoz, M. Polanco, I. Díaz, A. Susmozas, A.D. Moreno, M. Guirado, N. Carrerasand, M. Ballesteros, Biogas from Anaerobic Digestion as an Energy Vector: Current Upgrading Development, Energies, Vol. 14, 2021, 2742.

62. Illi L. , B. Lecker, A. Lemmer, J. Müller, H. Oechsnera, Biological methanation of injected hydrogen in a two-stage anaerobic digestion process, Bioresource Technology, Vol. 333, 2021, 125126.

63. Jayalakshmi S., K. Joseph, V. Sukumaran, Bio hydrogen generation from kitchen waste in an inclined plug flow reactors, Int. J. Hydrogen Energy, Vol. 34, 2009, 8854-8858.

64. Jeihanipour A., C. Niklasson, M.J. Taherzadeh, Enhancement of solubilization rate of cellulose in anaerobic digestion and its drawbacks, Process Biochem., Vol. 46, 2011, 1509-1514.

65. Kainthola J., A.S. Kalamdhad, V.V. Goud, A review on enhanced biogas production from anaerobic digestion of lignocellulosic biomass by different enhancement techniques, Process Biochem., Vol. 84, 2019, 81-90.

66. Kamyab B., H. Zilouei, Investigating the efficiency of biogas production using modelling anaerobic digestion of baker's yeast wastewater on two-stage mixed-UASB reactor, Fuel, Vol. 285, 2021, 119198.

67. Khalid A., M. Arshad, M. Anjum, T. Mahmood, L. Dawson, The anaerobic digestion of solid organic waste, Waste Manag., Vol. 31(8), 2011, 1737-1744.
68. Khan M A., H.H. Ngo, W. Guo, Y. Liu, L.D. Nghiem, F.I. Hai, L.J. Deng, J. Wang, Y. Wu, Optimization of process parameters for production of volatile fatty acid, biohydrogen and methane from anaerobic digestion, Bioresource technology, Vol. 219, 2016, 738-748.

69. Komilis D., R. Barrena, R.L. Grando, V. Vogiatzi, A. S' anchez, X. Font, A state of the art literature review on anaerobic digestion of food waste: influential operating parameters on methane yield, Rev. Environ. Sci. Biotechnol., Vol. 16, 2017, 347-360.

70. Kotsyurbenko O. R., Trophic interactions in the methanogenic microbial community of lowtemperature terrestrial ecosystems, FEMS Microbiology Ecology, Vol. 53(1), 2005, 3-13.

71. Kovalev A.A., D.A. Kovalev, A.N. Nozhevnikova, E.A. Zhuravleva, I.V. Katraeva, V.S. Grigoriev, Yu.V. Litti, Effect of low digestate recirculation ratio on biofuel and bioenergy recovery in a two-stage anaerobic digestion process, International Journal of Hydrogen Energy, vol. 46 (80), 2021, 39688-39699.

72. Kovalev A.A., D.A. Kovalev, E.A. Zhuravleva, I.V. Katraeva, V. Panchenko, U. Fiore, Y.V. Litti, Two-stage anaerobic digestion with direct electric stimulation of methanogenesis: The effect of a physical barrier to retain biomass on the surface of a carbon cloth-based biocathode, Renewable Energy, Vol. 181, 2022, 966-977.

73. Krishnan S., L. Singh, M. Sakinah, S. Thakur, M. Nastrul, A. A. Otleno, Z. A. Wahid, An investigation of two-stage thermophilic and mesophilic fermentation process for the production of hydrogen and methane from palm oil mill effluent, Environmental Progress \& Sustainable Energy, Vol. 36(3), 2016, 895-902.

74. Kumar A., S.R. Samadder, Performance evaluation of anaerobic digestion technology for energy recovery from organic fraction of municipal solid waste: a review, Energy, Vol. 197, 2020, 117253.

75. Kyazze G, R. Dinsdale, A.J. Guwy, F.R. Hawkes, G.C. Premier, D.L. Hawkes, Performance characteristics of a two-stage dark fermentative system producing hydrogen and methane continuously, Biotechnology and Bioengineering, Vol. 97, 2007, 759-770.

76. Lavagnolo M.C., F. Girottoa, R. Rafieeniaa, L. Danielia, L. Alibardi, Two-stage anaerobic digestion of the organic fraction of municipal solid waste - Effects of process conditions during batch tests, Renewable Energy, Vol. 126, 2018, 14-20.

77. Lay J.J., K.S. Fan, J.1 Chang, C.H. Ku, Influence of chemical nature of organic wastes on their conversion to hydrogen by heat-shock digested sludge, Int. J. Hydrogen Energy, Vol. 28(12), 2003, 1361-1367. 
78. Lay JJ., Biohydrogen generation by mesophilic anaerobic fermentation of microcrystal-line cellulose, Biotechnology and Bioengineering, Vol. 74, 2001, 281-287.

79.Li C., H.H.P. Fang, Fermentative hydrogen production from wastewater and solid wastes by mixed cultures, Critical Reviews in Environmental Science and Technology, Vol. 37, 2007, 1-39.

80.Li W.W., H.Q. Yu, Advances in EnergyProducing Anaerobic Biotechnologies for Municipal Wastewater Treatment, Engineering, Vol. 2, 2016, 438-446.

81.Lim J.W., T. Park, Y.W. Tong, Z. Yu, The microbiome driving anaerobic digestion and microbial analysis, Advances in Bioenergy, Vol. 5, 2020, 1-61.

82. Lin C.Y., C.H. Lay, A nutrient formulation for fermentative hydrogen production using anaeobic sewage sludge microflora, Int. J. Hydrogen Energy, Vol. 30, 2005, 285-292.

83. Liu S., X. Ge, F. Xu, Y. Li, Effect of total solids content on giant reed ensilage and subsequent anaerobic digestion, Process Biochem., Vol. 51, 2016, 73-79.

84.Liu X., R. Li, M. Ji, Effects of Two-Stage Operation on Stability andEfficiency in Co-Digestion of Food Waste and Waste Activated Sludge, Energies, Vol. 12, 2019, 2748.

85.Liu Y., W. B. Whitman, Metabolic, phylogenetic, and ecological diversity of the methanogenic archaea, Ann. N. Y. Acad. Sci., Vol. 1125, 2008, 171-189.

86.Lo H.M., M.H. Liu, T.Y. Pai, W.F. Liu, C.Y. Lin, S.C. Wang, C.J. Banks, C.H. Hung, C.F. Chiang, K.C. Lin, P.H. Chen, J.K. Chen, H.Y. Chiu, M.H. Su, T.A. Kurniawan, K.C. Wu, C.Y. Hsieh, H.S. Hsu, Biostabilization assessment of MSW co-disposed with MSWI fly ash in anaerobic bioreractors, Journal of Hazardous Materials, Vol. 162, 2009, 1233-1242.

87.Lynd L.R., P.J. Weimer, W.H. Van Zyl, I.S. Pretorius, Microbial cellulose utilization: fundamentals and biotechnology,. Microbiol. Molecular Biol. Rev., MMBR, Vol. 66(3), 2002, 506.

88. Ma G., Y. Chen, P. Ndegwa, Association between methane yield and microbiota abundance in the anaerobic digestion process: a meta-regression, Renew. Sustain. Energy Rev., Vol. 135, 2021, 110212.

89. Mamimin C., A. Singkhala, P. Kongjan, B. Suraraksa, P. Prasertsan, T. Imai, S. O-Thong, Twostage thermophilic fermentation and mesophilic methanogen process for biohythane production from palm oil mill effluent, International Journal of Hydrogen Energy, Vol. 40, 2015, 6319-6328.

90. Markphan W., C. Mamimin, W. Suksong, P. Prasertsan, S. O-Thong, Comparative assessment of single-stage and two-stage anaerobic digestion for biogas production from high moisture municipal solid waste, PeerJ, Vol. 8, 2020, 9693.

91. Martinez-Burgos W.J., E.B. Sydney, D. Rodrigues de Paula, A.B.P. Medeirosa, J. Cesar de Carvalho, D. Molina, C.R. Soccol, Hydrogen production by dark fermentation using a new low-cost culture medium composed of corn steep liquor and cassava processing water: Process optimization and scale-up, Bioresource Technology, Vol. 320, 2021, 124370.

92. Maspolim Y., Y. Zhou, C. Guo, K. Xiao, W. Jern $\mathrm{Ng}$, Comparison of single-stage and two-phase anaerobic sludge digestion systems - Performance and microbial community dynamics, Chemosphere, Vol. 140, 2015, 54-62.

93. Meena R.A.A., J.R. Banu, R.Y. Kannah, K.N. Yogalakshmi, G. Kumar, Biohythane production from food processing wastes - challenges and perspectives, Bioresour. Technol., Vol. 298, 2020, 122449.

94. Mirzoyan S., A. Trchounian, K. Trchounian, Hydrogen production by Escherichia coli during anaerobic utilization of mixture of lactose and glycerol: Enhanced rate and yield, prolonged production, Int. J. Hydrogen Energy, Vol. 44(18), 2019, 9272-9281.

95. Mohan S.V., G. Mohanakrishna, P.N. Sarma, Integration of acidogenic and methanogenic processes for simultaneous production of biohydrogen and methane from wastewater treatment, Int. J. Hydrogen Energy, Vol. 33, 2008, 2156-2166.

96. Mosier N., C. Wyman, B. Dale, R. Elander, Y.Y. Lee, M. Holtzapple, M. Ladisch, Features of promising technologies for pretreatment of lignocellulosic biomass, Bioresour. Technol., Vol. 96(6), 2005, 673-686.

97. Nabaterega R., V. Kumar, S. Khoei, C. Eskicioglu, A review on two-stage anaerobic digestion options for optimizing municipal wastewater sludge treatment process, Journal of Environmental Chemical Engineering, Vol. 9, 2021, 105502.

98. Najdenski H., V. Hubenov, I. Simeonov, V. Kussovski, L. Dimitrova, P. Petrova, P. Angelov, L. Kabaivanova, Microbial biodegradation as an option for waste utilization during long-term manned space missions, Bulgarian Chemical Communications, Vol. 52(3), 2020, 379-386.

99. Náthia-Neves G., T. de Alencar Neves, M. Berni, G. Dragone, S.I. Mussatto, T. Forster-Carneiro, Start-up phase of a two-stage anaerobic co-digestion process: hydrogen and methane production from food waste and vinasse from ethanol industry, Biofuel Research Journal, Vol. 18, 2018, 813-820.

100. Nguyen P.D., N.S.T. Tran, T.T. Nguyen, B.T. Dang, M.T.T. Le, X.T. Bui, F. Mukai, H. Kobayashi, H.H. Ngo, Long-term operation of the pilot scale two-stage anaerobic digestion of municipal 
biowaste in Ho Chi Minh City, Science of The Total Environment, Vol. 766, 2021, 142562.

101. Nizami A.S., J.D. Murphy, Optimizing the operation of a two-phase anaerobic digestion system digesting grass silage, Environmental Science \& Technology, Vol. 45(17), 2011, 7561-7569.

102. Notodarmojo P.A., T. Fujiwara, Habuer, D.P. Van, Effectiveness of oyster shell as alkali additive for two-stage anaerobic co-digestion: Carbon flow analysis, Energy, Vol. 239, 2022, 122177.

103. Nsair A., S.O. Cinar, A. Alassali, H.A. Qdais, K. Kuchta, Operational Parameters of Biogas Plants: A Review and Evaluation Study, Energies, Vol. 13, 2020, 3761.

104. Okudoh V., C. Trois, T. Workneh, S. Schmidt, The potential of cassava biomass and applicable technologies for sustainable biogas production in South Africa: A review, Renewable and Sustainable Energy Reviews, 39, 2014, 1035-1052.

105. Oremland R.S., In: Biology of Anaerobic Microorganisms, ed. by A.J.B. Zehnder, Biogeochemistry of Methanogenic Bacteria, Wiley Press, New York, 1988, 641-705.

106. O-Thong S., C. Mamimin, P. Prasertsan, Biohythane Production from Organic Wastes by TwoStage Anaerobic Fermentation Technology, Advances in Biofuels and Bioenergy, Chapter 5, IntechOupen, 2018.

107. O-Thong S., P. Prasertsan, N. Intrasungkha, S. Dhamwichukorn, N.K. Birkeland, Optimization of simultaneous thermophilic fermentative hydrogen production and COD reduction from palm oil mill effluent by Thermoanaerobacterium-rich sludge, International Journal of Hydrogen Energy, Vol. 33, 2008, 1221-1231.

108. Parawira W., M. Murto, J.S. Read, B. Mattiasson, A study of two-stage anaerobic digestion of solid potato waste using reactors under mesophilic and thermophilic conditions, Environmental Technology, Vol. 28, 2007, 1205-1216.

109. Pramanik S.K., F.B. Suja, S.M. Zain, B.K. Pramanik, The anaerobic digestion process of biogas production from food waste: prospects and constraints, Bioresource Technology Reports, Vol. 8, 2019, 100310.

110. Rabii A., S. Aldin, Y. Dahman, E. Elbeshbishy, A Review on Anaerobic Co-Digestion with a Focus on the Microbial Populations and the Effect of Multi-Stage Digester Configuration, Energies, Vol. 12, 2019, 106.

111. Rafieenia R., A. Pivato, M.C. Lavagnolo, Effect of inoculum pre-treatment on mesopphilic hydrogen and methane production from food waste using two-stage anaerobic digestion, Int. J. Hydrogen Energy, Vol. 43, 2018, 12013-12022.
112. Rajagopal R., M.R. Choudhury, N. Anwar, B. Goyette, M.S. Rahaman, Influence of PreHydrolysis on Sewage Treatment in an Up-Flow Anaerobic Sludge BLANKET (UASB) Reactor: A Review, Waste, Vol. 11, 2019, 372.

113. Ramadhani L.I., S.I. Damayanti, H. Sudibyo, M.M. Azis, W. Budhijanto, The impact of hydraulic retention time on the biomethane production from palm oil mill effluent (POME) in two-stage anaerobic fluidized bed reactor, Int. Journal of Renewable Energy Development, Vol. 10(1), 2021, 11-16.

114. Ramos L.R., G. Lovato, J.A.D. Rodrigues, E.L. Silva, Anaerobic digestion of vinasse in fluidized bed reactors: Process robustness between two-stage thermophilic-thermophilic and thermophilicmesophilic systems, Journal of Cleaner Production, Vol. 314, 2021, 128066.

115. Rasapoor M., B. Young, A. Sarmah, W.Q. Zhuang, S. Baroutian, Recognizing the challenges of anaerobic digestion: critical steps toward improving biogas generation, Fuel, Vol. 261, 2020, 116497.

116. Rivière D., V. Desvignes, E. Pelletier, S. Chaussonnerie, S. Guermazi, J. Weissenbach, T. Li, P. Camacho, A. Sghir, Towards the definition of a core of microorganisms involved in anaerobic digestion of sludge, ISME J., Vol. 3, 2009, 700-714.

117. Rocamora I., S.T. Wagland, R. Villa, E.W. Simpson, O. Fern' andez, Y. Baj' on-Fernandez, Dry anaerobic digestion of organic waste: a review of operational parameters and their impact on process performance, Bioresour. Technol., Vol. 299, 2020, 122681.

118. Rodriguez C.E.R., V. Alcaraz-González, J.P. García-Sandoval, V. González-Álvarez, H.O. MéndezAcosta, Modelling and parameter estimation of a twostage anaerobic digestion system for the treatment of tequila vinasses, Conference: 13th World Congress on Anerobic Digestion, June 2013.

119. Romero-Güiza M.S., J. Vila, J. MataAlvarez, J.M. Chimenos, S. Astals, The role of additives on anaerobic digestion: A review, Renewable and Sustainable Energy Reviews, Vol. 58, 2016, 14861499.

120. Ruggeri B., T. Tommasi, S. Sanfilippo, BioH2\&BioCH4 through anaerobic digestion (From research to full-scale applications), Springer, 2015, $215 \mathrm{p}$.

121. Rusín J., K. Chamrádová, P. Basinas, Twostage psychrophilic anaerobic digestion of food waste: Comparison to conventional single-stage mesophilic process, Waste Management, Vol. 119, 2021, 172-182.

122. Salomoni C., A. Caputo, M. Bonoli, O. Francioso, M.T. Rodriguez-Estrada, D. Palenzona, Enhanced methane production in a two-phase anaerobic digestion plant, after $\mathrm{CO}_{2}$ capture and 
addition to organic wastes, Bioresource Technology, Vol. 102, 2011, 6443-6448.

123. Sani K., P. Kongjan, C. Pakhathirathien, B. Cheirsilp, S. O-Thong, M. Raketh, R. Kana, R. Jariyaboon, Effectiveness of using two-stage anaerobic digestion to recover bio-energy from high strength palm oil mill effluents with simultaneous treatment, Journal of Water Process Engineering, Vol. 39, 2021, 101661 .

124. Schievano A., A. Tenca, S. Lonati, E. Manzini, F. Adani, Can two-stage instead one-stage anaerobic digestion really increase energy recovery from biomass?, Applied Energy, Vol. 124, 2014, 335342.

125. Sevillano C.A., A.A. Pesantes, E.P. Carpio, E.J. Martínez and X. Gómez, Anaerobic Digestion for Producing Renewable Energy - The Evolution of This Technology in a New Uncertain Scenario, Entropy, Vol. 23, 2021, 145.

126. Shi Z., R. Zhao, J. Wan, B. Li, Y. Shen, S. Zhang, G. Luo, Metagenomic analysis reveals the fate of antibiotic resistance genes in two-stage and onestage anaerobic digestion of waste activated sludge, Journal of Hazardous Materials, Vol. 406, 2021, 124595.

127. Shin S.G., G. Han, J. Lim, C. Lee, S. Hwang, A comprehensive microbial insight into two-stage anaerobic digestion of food waste-recycling wastewater, Water Research, Vol. 44, 2010, 4838-4849.

128. Silva F.M.S., C.F. Mahler, L.B. Oliveira, J.P. Bassin, Hydrogen and methane production in a twostage anaerobic digestion, system by co-digestion of food waste, sewage sludge and glycerol, Waste Management, Vol. 76, June 2018, 339-349.

129. Simeonov I., B. Kalchev, S. Mihaylova, V. Hubenov, G. Valevski, A. Aleksandrov, R. Georgiev, Pilot-scale biogas plant for research and development of new technologies, Ecological Engineering and Environment protection, 2012, 263-71 (in Bulgarian).

130. Simeonov I., E. Chorukova, Mathematical Modeling of the Anaerobic Digestion with Production of Hydrogen and Methane, The 4th International Conference on Water, Energy and Environment (ICWEE), Burgas, June 1-2, 2016, 32-38.

131. Simeonov I., E. Chorukova, S. Diop, N. Christov, Pilot scale biogas reactor with computer system for monitoring and control, Proc. of Septième édition du COlloque FRancophone en Energie, Environnement, Economie et Thermodynamique COFRET'14, Paris, France, Avril 23-25, 2014, 711-723.

132. Simeonov I., Laboratory studies and mathematical modeling of the anaerobic digestion in a cascade of two bioreactors, Ecological Engineering and Environment protection, Vol. 2, 2005, 51-57 (in Bulgarian).
133. Simeonov I., V. Hubenov, E. Chorukova, Renewable energy from two-stage anaerobic digestion of organic wastes, 17-th International Conference on Electrical Machines, Drives and Power Systems (ELMA), 1-4 July 2021, Sofia, Bulgaria.

134. Sposob M., J.Y. Nam, J.G. Park, T.H. Kim, Y. Hwang, S.M. Jeong, Y.M. Yun, Starvation pretreatment enhances sulfidogenic operation of twostage anaerobic digestion system for biogas production with low $\mathrm{H}_{2} \mathrm{~S}$ content, Journal of Cleaner Production, Vol. 290, 2021, 125166.

135. Srisowmeya G., M. Chakravarthy, G.N. Devi, Critical considerations in two-stage anaerobic digestion of food waste - a review, Renew. Sustain. Energy Rev., Vol. 119, 2020, 109587.

136. Stanier R.Y., L.J. Ingraham, L. Mark, P.D. Wheelis, P.R. Painter, The Microbial World, Prentice Hall, Englewood Cliffs, 1986.

137. Stella B.S., M.O. Faber, A.C.A. Colla, E.C.G. Aguieiras, D.M.G. Freire, M.A.P. Langone, Sequential hydrogen and methane production using the residual biocatalyst of biodiesel synthesis as raw material, International Journal of Hydrogen Energy, Vol. 46(46), 6 July 2021, 23658-23669.

138. Sun C., L. Guo, Y. Zheng, D. Yu, C. Jin, Y. Zhao, Z. Yao, M. Gao, Z. She, Effect of mixed primary and secondary sludge for two-stage anaerobic digestion (AD), Bioresource Technology, Vol. 343, 2022, 126160.

139. Szostak-Kotowa J., International Biodeter, Biodegrad., Vol. 53, 165, 2004.

140. Tashyrev O. B., N. A. Matvieieva, V. M. Hovorukha, H. O. Tashyreva, O. Iu. Bielikova, O. A. Havryliuk, V. P. Duplij, Application of lignocellulosic substrate obtained after hydrogen dark fermentation of food waste as biofertilizer, Industrial biotechnology, 14 (6), 2018, 315-322.

141. Tena M., M. Perez, R. Solera, Effect of hydraulic retention time on the methanogenic step of a two-stage anaerobic digestion system from sewage sludge and wine vinasse: Microbial and kinetic evaluation, Fuel, Vol. 296, 2021, 120674.

142. Tsigkou K., D. Zagklis, P. Tsafrakidou, P. Zapanti, G. Manthos, K. Karamitou, C. Zafiri, M. Kornaros, Expired food products and used disposable adult nappies mesophilic anaerobic co-digestion: Biochemical methane potential, feedstock pretreatment and two-stage system performance, Renewable Energy, Vol. 168, 2021, 309-318.

143. Van Niel E., P. Claassen, A. Stams, Substrate and product inhibition of hydrogen production by the extreme thermophile, Caldicellulosiruptor saccharolyticus, Biotechnology and Bioengineering, Vol. 81, 2003, 255-262.

144. Vital-Jacome M.A, G. Buitron, Thermophilic anaerobic digestion of winery effluents in a two- 
stageprocess and the effect of the feeding frequency on methane production, Chemosphere, Vol. 272, 2021, 129865.

145. Wade Matthew J., Not Just Numbers: Mathematical Modelling and Its Contribution to Anaerobic Digestion Processes, Processes, Vol. 8, 2020,888 .

146. Wainaina S., Lukitawesa, M.K. Awasthi \& M.J. Taherzadeh, Bioengineering of anaerobic digestion for volatile fatty acids, hydrogen or methane production: A critical review, Bioengineering, Vol. 10(1), 2019, 437-458.

147. Wang Q., Y. Liang, P. Zhao, Q. Li, S. Guo, C. Chen, Potential and optimization of two-phase anaerobic digestion of oil refinery waste activated sludge and microbial community study, Sci Rep, Vol. 6, 2016, 38245 .

148. Wang X., Y. Zhao, A bench scale study of fermentative hydrogen and methane production from food waste in integrated two-stage process, Int. J. Hydrogen Energy, Vol. 34, 2009, 245-254.

149. Watts S., G. Hamilton, J. Keller, Two-stage thermophilic-mesophilic anaerobic digestion of waste activated sludge from a biological nutrient removal plant, Water Science and Technology, Vol. 53, 2006, 149-157.

150. Weiland P., State of the art of solid-state digestion-recent developments, Solid-state digestion state of the art and further R\&D requirements, Vol. 24, 2006, 22-38.

151. Weinrich S., M. Nelles, Basics of Anaerobic Digestion - Biochemical Conversion and Process Modelling, DBFZ Deutsches Biomasseforschungszentrum, Leipzig, 2021.

152. Xiao B., Y. Qin, J. Wu, H. Chen, P. Yu, J. Liu, Y.Y. Li, Comparison of single-stage and twostage thermophilic anaerobic digestion of food waste: Performance, energy balance and reaction process, Energy Conversion and Management, Vol. 156, 2018, 215-223.

153. Xu R., K. Zhang, P. Liu, A. Khan, J. Xiong, F. Tian, X. Li, A critical review on the interaction of

\section{Simeonov, L. Kabaivanova, E. Chorukova}

The Stephan Angeloff Institute of Microbiology, Bulgarian Academy of Sciences

Acad. G. Bonchev Str., B1. 26

1113 Sofia, Bulgaria

e-mail: issim@abv.bg substrate nutrient balance and microbial community structure and function in anaerobic co-digestion, Bioresour. Technol., Vol. 247, 2018, 1119-1127.

154. Yabu H., C. Sakai, T. Fujiwara, N. Nishio, Y. Nakashimada, Thermophilic two-stage dry anaerobic digestion of model garbage with ammonia stripping, Journal of Bioscience and Bioengineering, Vol. 111(3), 2011, 312-319.

155. Yan W., V. Vadivelu, Y. Maspolim, Y. Zhou, In-situ alkaline enhanced two-stage anaerobic digestion system for waste cooking oil and sewage sludge co-digestion, Waste Management, Vol. 120, 2021, 221-229.

156. Yang L., F. Xu, X. Ge, Y. Li, Challenges and strategies for solid-state anaerobic digestion of lignocellulosic biomass, Renew. Sustain. Energy Rev., Vol. 44, 2015, 824-834.

157. Yao Y., G. Huang, C. An, X. Chen, P. Zhang, X. Xin, J. Shen, J. Agnew, Anaerobic digestion of livestock manure in cold regions: technological advancements and global impacts, Renew. Sustain. Energy Rev., Vol. 119, 2020, 109494.

158. Yun Y.M., M.K. Lee, S.W. Im, A. Marone, E. Trably, S.R. Shin, M.G., Kim, S.K. Cho, D.H. Kim, Biohydrogen production from food waste: current status, limitations, and future perspectives, Bioresour. Technol., Vol. 248(A), 2018, 79-87.

159. Zhang S., Y. Wang, J. Song, C. Sheng, Z. Shang, R. Wang, X. Wang, G. Yang, Y. Feng, G. Ren, Investigation on the Interactive Effects between Temperature and Chemical Composition of Organic Wastes on Anaerobic Co-Digestion Performance, Processes, Vol. 9, 2021, 1682.

160. Zhang W., Q. Xie, J.D. Rouse, S. Qiao, K. Furukawa, Treatment of high-strength corn steep liquor using cultivated Polyvinyl alcohol gelbeads in an anaerobic fluidized-bed reactor, J. Bioscience and Bioengineering, Vol. 107(1), 2009, 49-53.

161. Zhu H., M. Béland, Evaluation of alternative methods of preparing hydrogen producing seeds from digested wastewater sludge, Int. J. Hydrogen Energy, Vol. 31, 2006, 1980-1988. 